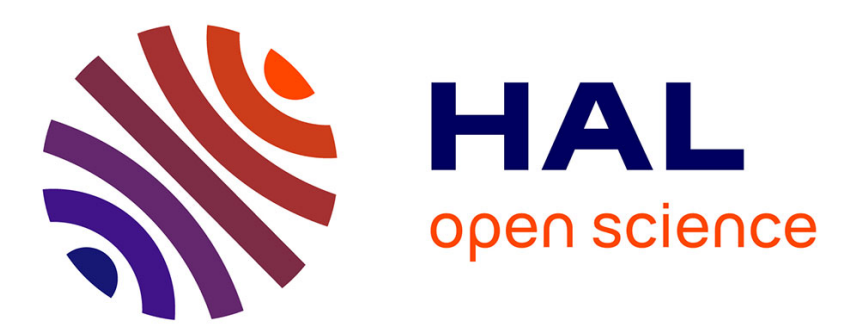

\title{
Oxidation Resistance of Thermal Barrier Coatings Based on Hollow Alumina Particles
}

\author{
F. Pedraza, M. Mollard, B. Rannou, B. Bouchaud, J. Balmain, G. Bonnet
}

\section{To cite this version:}

F. Pedraza, M. Mollard, B. Rannou, B. Bouchaud, J. Balmain, et al.. Oxidation Resistance of Thermal Barrier Coatings Based on Hollow Alumina Particles. Oxidation of Metals, 2016, 85 (3-4), pp.231-244. 10.1007/s11085-015-9570-3 . hal-02484849

\section{HAL Id: hal-02484849 \\ https://hal.science/hal-02484849}

Submitted on 19 Feb 2020

HAL is a multi-disciplinary open access archive for the deposit and dissemination of scientific research documents, whether they are published or not. The documents may come from teaching and research institutions in France or abroad, or from public or private research centers.
L'archive ouverte pluridisciplinaire HAL, est destinée au dépôt et à la diffusion de documents scientifiques de niveau recherche, publiés ou non, émanant des établissements d'enseignement et de recherche français ou étrangers, des laboratoires publics ou privés. 


\section{OXIDATION RESISTANCE OF THERMAL BARRIER COATINGS BASED ON HOLLOW}

\section{ALUMINA PARTICLES}

F. Pedraza*, M. Mollard, B. Rannou, B. Bouchaud, J. Balmain, G. Bonnet

LaSIE UMR7356 CNRS-Université de La Rochelle, Pôle Sciences et Technology, 17042 La Rochelle, FRANCE

* corresponding author: fpedraza@univ-lr.fr.fr

\section{Abstract}

Thermal barrier coatings were synthesized in a single step process from a slurry containing Al microspheres onto different Ni-based superalloys. Upon growth of the coating a top coat of hollow alumina spheres linked to an aluminium diffused coating through an alumina TGO formed. The isothermal and cyclic oxidation tests at different temperatures $\left(900\right.$ till $\left.1100^{\circ} \mathrm{C}\right)$ up to $1000 \mathrm{~h}$ or 1500 cycles revealed progressive growth of different thermal oxides depending on the substrate composition. Faster degradation of the coatings occurred in the titanium-rich substrates (e.g. IN-738LC and PWA1483) compared to the titanium-poor ones (CM-247LC and René N5). By comparing with conventional low activity aluminide coatings, it appeared that the incorporation of alloying elements (notably Ti and Ta) to the diffused layers upon the high activity slurry coating process is responsible for such fastest degradation.

Keywords: slurry aluminide; superalloys; isothermal oxidation; cyclic oxidation.

\section{INTRODUCTION}

The use of thermal barrier coatings (TBCs) in the high pressure turbine components of aeroengines made of nickel based superalloys is compulsory nowadays to withstand the very high surface temperatures of the corrosive gas released from the combustion chamber. This system is often based on a top ceramic coat of yttria stabilized zirconia (YSZ) made by electron beam physical vapour 
deposition (EB-PVD) with columnar structure to comply with thermal cycling, an intermediate $\alpha$ $\mathrm{Al}_{2} \mathrm{O}_{3}$ thermally grown oxide (TGO) to attach the YSZ and to provide oxidation protection and an underlying $\beta$-NiPtAl diffusion coating that acts as an aluminium reservoir [1]. New low-cost and environmentally friendly coatings were recently proposed in the European project "Particoat" [2] in which a water-based slurry containing Al microparticles was sprayed and annealed [3] onto pure nickel [4] and different nickel-based superalloys [5] or steels [6]. The isothermal oxidation behaviour of these coatings onto a pure Ni [7] and a René N5 superalloy [8] indicated faster oxidation kinetics and faster $\beta-\mathrm{NiAl} \rightarrow \gamma^{\prime}-\mathrm{Ni}_{3} \mathrm{Al}$ transformation than in conventional low activity $\beta$-NiAl although both systems grew duplex $\mathrm{NiAl}_{2} \mathrm{O}_{4} / \mathrm{Al}_{2} \mathrm{O}_{3}$ scales. In contrast, the presence of the hollow alumina top coat and the precipitates segregated at the thermally grown oxide limited the appearance of rumpling compared to the conventional coatings. Nevertheless, the incorporation of alloying elements from the substrate to the coating (e.g. titanium, tantalum, chromium...) may affect the corrosion/oxidation resistance of such coatings. Indeed, as pointed out by Evans et al. the bond coat is the most crucial component of the TBC system as its chemistry and microstructure influence durability through the structure and morphology of the TGO upon oxidation [9]. For instance, titanium grew non protective $\mathrm{TiO}_{2}$ on nanocrystalline IN738 superalloy [10] whereas interspersed tantalum rich oxide particles $\left(\mathrm{CrTaO}_{4} / \mathrm{NiTa}_{2} \mathrm{O}_{6}\right)$ developed in the top spinel $\left(\left(\mathrm{Ni}(\mathrm{Cr}, \mathrm{Al}, \mathrm{Co})_{2} \mathrm{O}_{4}\right)\right.$ scale on PWA-1484 superalloy [11]. It therefore appears that further understanding in this field is required for these new single step thermal barrier coatings sintered from a slurry. For such purpose, the increasing amounts of alloying elements in the superalloys and their incorporation to the coatings, hence into the oxide layers were investigated in this work. The evolution of the diffusion coatings in terms of $\beta-\mathrm{NiAl} \rightarrow \gamma^{\prime}-\mathrm{Ni}_{3} \mathrm{Al}$ and growth of topological closepacked phases (TCPs) will be also considered to shed light on the durability of these new slurry coatings. 


\section{EXPERIMENTAL}

The slurry TBCs were obtained from a $1 / 10$ PVA/ $\mathrm{H}_{2} \mathrm{O}$ solution to which 45 mass $\% 5 \mu$ m-sized $\mathrm{Al}$ microparticles were added [3]. After spray onto four nickel-based superalloys with different composition and crystal structure (Table 1) and dry in air, the slurries were annealed at $700^{\circ} \mathrm{C} / 2 \mathrm{~h}$ and additional $1100^{\circ} \mathrm{C} / 2 \mathrm{~h}$ in $\operatorname{Ar}(\mathrm{g})$. The traces of $\mathrm{O}_{2}(2 \mathrm{vpm})$ and $\mathrm{H}_{2} \mathrm{O}(5 \mathrm{vpm})$ in Ar were shown to be sufficient to grow the top coat and the TGO composed of hollow and plain $\alpha-\mathrm{Al}_{2} \mathrm{O}_{3}$, respectively [4]. The slurry TBCs were compared with industrially manufactured low activity out-of-pack (70Cr-30Al donor, $\mathrm{NH}_{4} \mathrm{~F}$ activator, treated at $1080^{\circ} \mathrm{C}$ for $6 \mathrm{~h}$ in vacuum) and high activity pack cemented $(60 \mathrm{Cr}$ $40 \mathrm{Al}$ donor, $\mathrm{NaCl}$ activator, $\mathrm{Al}_{2} \mathrm{O}_{3}$ filler treated at $860^{\circ} \mathrm{C}$ for $6 \mathrm{~h}$ in argon and subsequently annealed at $1120^{\circ} \mathrm{C}$ for $2 \mathrm{~h}$ in vacuum).

Short (100h) isothermal tests were performed in a Setaram TGA92 thermobalance while for the long term (500 and $1000 \mathrm{~h})$ tests a Pyrox furnace was employed. In both cases, purging with $\operatorname{Ar}(\mathrm{g})$ was let in the chamber till the oxidizing temperatures $\left(900,1000,1100^{\circ} \mathrm{C}\right)$ were reached and synthetic air replaced $\operatorname{Ar}(\mathrm{g})$. For the cyclic oxidation tests at 1000 and $1100^{\circ} \mathrm{C}$ ambient air was employed in a Delta Thermique furnace. The thermal cycles corresponded to a hot dwell of $45 \mathrm{~min}$ after which the samples were quenched by air flow for $15 \mathrm{~min}$ to reach surface temperatures of $40( \pm 10)^{\circ} \mathrm{C}$. Note however that the oxidation temperatures depended on the limit operating temperature of the substrates as gathered in Table 2. X-ray diffraction (XRD, Bruker AXS D8, $\mathrm{Ka}_{\mathrm{Cu}}=0.15406 \mathrm{~nm}$ ), Raman spectroscopy (Jobin Yvon Horiba LabRam HR, $\lambda=632.817 \mathrm{~nm}$ ), light microscopy (Leica M165C), scanning electron microscopy with a coupled energy dispersive energy spectrometer (SEM/EDS, FEI-Quanta 200F/EDAX and JEOL5410/Oxford) and Electron probe microanalysis (EPMA, JEOL JXA-1800) allowed to characterize the degradation of the coatings in the as-deposited condition and after oxidation.

\section{RESULTS AND DISCUSSION}




\section{1.- Coatings}

All the slurry coatings displayed the same structure as the one given in Figure 1 with a top coat of hollow alumina spheres, a very thin thermally grown alumina scale and a bottom aluminium diffused layer. In the backscattered electron mode of SEM and by EPMA some nickel was revealed at the top coat. A schematic illustration gathering the major mechanisms of formation of these coatings is included in Figure 2. Such mechanisms were thoroughly described in previous works $[4,12,13]$. Once the slurry containing the passivated Al microparticles is dried and annealing at sufficiently high temperatures starts, the phase transformation of the alumina shell surrounding the Al particles results in cracks through which $\mathrm{Al}$ diffuses out and wets the Ni-based substrate [4]. Then, Ni dissolves in molten $\mathrm{Al}$ [12] and the subsequent greatly exothermic reactions between $\mathrm{Al}$ and $\mathrm{Ni}$ bring about the synthesis of the Al-rich nickel aluminides by a self-propagating combustion mechanism [13]. Once all molten $\mathrm{Al}$ is consumed, solid state interdiffusion occurs, in particular upon the final temperature step of the synthesis process. However, the roughness of the interface between the top coat and the diffused layer increased with greater alloying element content in the substrate (Figure 3). Galetz et al. [13] proposed that molten $\mathrm{Al}$ builds a network between the $\mathrm{Al}$ particles at the top and the substrate surface resulting in a "stalagmite" microstructure that is more pronounced when using greater particles [14]. Here, the segregation of precipitates at the surface of the substrate seemed to limit the contact between $\mathrm{Ni}$ and $\mathrm{Al}$, thus reducing the local temperature released from the great exothermal $\mathrm{Ni}-\mathrm{Al}$ reactions. As a result, molten Al cannot homogeneously hit the substrate when compared to the absence of precipitates. In addition, and although different microstructures of the diffused layers were obtained depending on the initial composition and crystal structure of the Ni-based superalloys investigated, they all exhibited a typical microstructure of high activity aluminides also observed by Montero et al. on similar CM-247, IN-738 and René 80 superalloy substrates than ours [5]. In yet unpublished results, the EPMA X-ray maps of the slurry coatings revealed increasing partition of $\mathrm{Ti}$ and $\mathrm{Ta}$ to the $\mathrm{TGO} /$ diffusion coating interface and of $\mathrm{Cr}$ to the top of the diffusion layer with increasing content in 
the substrate alloy, e.g. more Ti segregated in PWA-1483 (4.1 mass \%Ti) than in CM-247 (0.7 mass \% Ti). The precipitates in the pack cemented coatings distributed very similarly to the slurry ones while the out-of-pack barely contained any precipitate as was also the case for slurry on pure $\mathrm{Ni}$ [4].

\section{2- Isothermal oxidation}

The parabolic rate constants calculated using the complete law approach [15] were plotted in the Arrhenius diagram derived from a bulk $\beta$-NiAl by Brumm and Grabke [16] in Figure 4. It appeared that the slurry coatings onto pure nickel grew transition $\theta-\mathrm{Al}_{2} \mathrm{O}_{3}$ for the first $100 \mathrm{~h}$ regardless of the oxidation temperature. In contrast, the coated superalloys exhibited an evolution from $\theta$ to $\alpha-\mathrm{Al}_{2} \mathrm{O}_{3}$ with increasing temperature in agreement with the well-known third element effect that $\mathrm{Cr}$ procures to develop $\alpha-\mathrm{Al}_{2} \mathrm{O}_{3}$ scales rapidly [17]. However, one must bear in mind that the greatest kinetics of the slurry coatings can be related to further oxidation of remnants of metallic $\mathrm{Al}$ in the spheres after the coating elaboration process [7]. Further extension to 500 and $1000 \mathrm{~h}$ of oxidation displayed less differences in terms of specific mass gain compared to a low activity $\beta$-NiAl. A similar slurry coating onto CM-247LC superalloy oxidised by Montero et al. at $1000^{\circ} \mathrm{C}$ for $1000 \mathrm{~h}$ displayed in contrast much greater mass gains than a conventional high activity pack cemented coating but the mass gains were reduced by previous blasting of the top coat [18]. It shall be noted however that the top coat partially detached depending on the substrate (coating) composition (Table 3) likely during the cooling step ( $\left.50^{\circ} \mathrm{C} / \mathrm{min}\right)$.

This hypothesis was confirmed from the X-ray patterns (Table 3), where the incorporation of titanium and tantalum oxides became more relevant with oxidation time in all the systems. Additional tungsten, hafnium and spinel oxides appeared on N5, CM and PWA substrates. The EDS elemental maps in the cross sections confirmed the XRD results. Cr mainly partitioned to the interdiffusion zone (IDZ) [19] 
and therefore could not contribute to the formation of $\mathrm{Cr}_{2} \mathrm{O}_{3}$. In contrast, Ta and Ti were found in both at the bond coat/TGO interface and within the IDZ. Such partition was previously reported by Bouchaud et al. for Ta [20] and by Pfening and coll. for Ti [21] and can be related to the relatively high diffusion coefficient of both refractory elements in these coating and alloy systems [22]. It was also noted that upon transformation of the $\beta-\mathrm{NiAl} \rightarrow \gamma^{\prime}-\mathrm{Ni}_{3} \mathrm{Al}$, dissolution of the precipitates of refractory elements occurred with temperature and time because of their limited solubilities in the $\beta-\mathrm{NiAl}$ phase [e.g. 22].

This is clearly demonstrated in Figure 5, where the low activity out-of-pack bond coat transformed less $\beta$-NiAl phase than the high activity slurry one and therefore refractory-rich oxides precipitated in the duplex oxide scale with $\mathrm{NiAl}_{2} \mathrm{O}_{4}$ on top of a $\alpha-\mathrm{Al}_{2} \mathrm{O}_{3}$ grown in both coating systems. However, and in spite of further transformation of $\beta-\mathrm{NiAl}$ into the $\mathrm{L}_{2}$ (or martensitic $\mathrm{L}_{0}$ ) $\gamma^{\prime}-\mathrm{Ni}_{3} \mathrm{Al}$ quoted to induce rumpling $[23,24]$ in the slurry coatings than in the conventional CVD ones, the latter displayed a more rumpled surface. It therefore appeared that the presence of the refractory oxide precipitates within the scale and the top coat of hollow alumina particles allowed to pin the TGO and the underlying bond. As summarised in Table 4, Al diffusion into the substrate brought about the precipitation of TCPs, whose extent and composition depended on temperature and time and they can lead to a degradation of the mechanical properties upon mechanical loading [19]. The greater the temperature and time, the thicker the extent of the TCPs area except for CM-247LC since the precipitates seemed to solubilize in the $\gamma / \gamma^{\prime}$ matrix. Additional needle-like precipitates in this area can also ascribed to AlN $[25,26]$ with $\mathrm{N}$ from the substrate diffusing outwardly [27,28]. Similar TCPs were also found in the low activity out-of-pack aluminides after oxidation in terms of morphology and extension in a DS superalloy having a composition very alike to that of CM-247LC [20].

\section{1.- Cyclic oxidation}

Figure 6 displays the mass gains per surface unit of René N5 and PWA 1483 aluminized using the 
conventional low activity and the slurry methods upon cyclic oxidation at $1100^{\circ} \mathrm{C}$ in air. Compared to the low activity aluminide, some spallation compensated by further mass gains occurred in the slurry René N5. In contrast, the slurry PWA 1483 underwent significant mass losses in less than 100 cycles. Since the major mass loss can be attributed to the top coat of hollow spheres, it appears that quite extended areas became naked (see inset in Fig. 5). The naked surface displayed a dark yellow colour indicative of $\mathrm{TiO}_{2}$ and the presence of this oxide was confirmed by Raman spectroscopy and XRD. Therefore, it can be considered $\mathrm{TiO}_{2}$ as the cause of such spallation. Indeed, by decreasing the oxidation temperature to $1000^{\circ} \mathrm{C}$ (Figure 7), the top coat remained adherent until 1500 cycles of oxidation although some low intensity peaks of $\mathrm{TiO}_{2}$ were detected together with those of the major $\alpha-\mathrm{Al}_{2} \mathrm{O}_{3}$ and $\mathrm{NiAl}_{2} \mathrm{O}_{4}$ spinel oxide phases.

The evolution of the coating microstructure with cycling was similar to the one observed under isothermal regime. However, the $\beta-\mathrm{NiAl} \rightarrow \gamma^{\prime}-\mathrm{Ni}_{3} \mathrm{Al}$ transformation was comparatively less extended while the rumpling phenomenon was greater than in isothermal regime. Although the rumpling phenomenon is often reported to result from the volume change induced upon the $\beta \rightarrow \gamma$ ' phase transformation [24,29], additional factors such as the differences of thermal expansion coefficients between the scale and the coating [30] and the coating and the substrate [31] in addition to the lateral growth of the scale [32] shall be also considered. Here, the precipitate-free aluminide coatings obtained by out-of-pack rumpled more than the slurry ones (Figure 8) and therefore confirms the pinning effect of both the precipitates in the coatings that limit the plastic deformation like in a composite material and of the top coat since the expansion and contraction of hollow spheres likely limit the introduction of additional stresses to the TGO.

As result of interdiffusion, the composition of such TGO also evolved with the number of cycles at temperature. In particular, and as with the isothermal regime, Ta and Ti diffused outwardly and 
incorporate in the TGO like in the examples shown in Figure 9 for the X-ray elemental maps of the slurry aluminised René N5 after 1000 cycles of oxidation at $1100^{\circ} \mathrm{C}$ and in Table 4 with the phases identified by XRD after different cycles of oxidation at $1000^{\circ} \mathrm{C}$ of the slurry, out-of-pack and pack cemented aluminides in PWA-1483. In the former, the maps clearly revealed major segregation on top of the Al-rich TGO likely resulting in mixed $\mathrm{CrTaO}_{4} / \mathrm{NiTa}_{2} \mathrm{O}_{6}$ or simple $\mathrm{TaO}_{2}$ oxides [11]. In the latter, $\mathrm{TiO}_{2}$ was unambiguously identified from 500 cycles onwards in the high activity (slurry and pack) aluminides in addition to the major contribution of $\alpha-\mathrm{Al}_{2} \mathrm{O}_{3}$ but was absent in the precipitate-free low activity out-of-pack aluminide. Such $\mathrm{TiO}_{2}$ segregation was quoted to result from the very coating process itself [8] but additional outward diffusion could occur upon the increased $\beta-\mathrm{NiAl} \rightarrow \gamma^{\prime}-\mathrm{Ni}_{3} \mathrm{Al}$ transformation of the high activity aluminides since Ti partitions to $\mathrm{Ni}_{3} \mathrm{Al}$ [33]. In spite of a greater relative intensity of $\mathrm{TiO}_{2}$ with respect the $\mathrm{NiAl}_{2} \mathrm{O}_{4}$ spinel all the scales (and top coat) appeared adherent even after 1500 cycles.

In addition, the extent of the TCPs area also increased with temperature and time in a similar fashion than in the isothermal regime (Table 4). The thickness of the TCP extension was very alike in both high activity coatings but was slightly thicker in the out-of-pack ones probably from their greater initial Al content. Nevertheless, these results are very much in agreement with those proposed in the open literature for different aluminised nickel-based superalloy substrates [e.g. 24] and demonstrate the overall similar degradation mechanisms of these new slurry coatings to the conventional out-of-pack and pack aluminides.

\section{CONCLUSIONS}

The slurry coatings grown through a high activity process underwent relatively faster oxidation kinetics than bulk $\beta$-NiAl materials at the different temperatures investigated (900, 1000 and $\left.1100^{\circ} \mathrm{C}\right)$. Although remnants of metallic Al may contribute to the overall mass gain, the formation of titanium and tantalum oxides very likely enhanced growth of the oxide scales that were mainly based on a top 
$\mathrm{NiAl}_{2} \mathrm{O}_{4}$ and a bottom $\alpha-\mathrm{Al}_{2} \mathrm{O}_{3}$. These detrimental oxides grew with increasing oxidation temperature in particular in the Ti and Ta-rich alloys. However, $\mathrm{Cr}$ remained trapped in the TCP phases and did not influence the oxidation kinetics. Although the oxidation kinetics and the $\beta-\mathrm{NiAl} \rightarrow \gamma^{\prime}-\mathrm{Ni}_{3} \mathrm{Al}$ transformation were enhanced in the high activity slurry coatings, the refractory-rich precipitates at the hollow spheres top coat/diffusion layer interface and the presence of the top coat seemed to limit rumpling compared to the conventional low activity $\beta$-NiAl ones. Nevertheless, extensive growth of $\mathrm{TiO}_{2}$ appears to be the major cause of spallation as demonstrated in the cyclic oxidation tests and therefore the operating temperature for the high activity coatings rich in Ti shall not surpass $1000^{\circ} \mathrm{C}$.

\section{Acknowledgements}

The DECHEMA Forschung Institut (Germany) is gratefully acknowledged for the EPMA analyses. SR Technics Airfoil Services (Ireland) and Turbocoating (Italy) kindly provided, respectively, the low activity out-of-pack and the pack cemented coatings. This study was performed under the programme PARTICOAT FP7-NMP-2007-LARGE-1-CP-IP-211329-2 (2008-2012) funded by the European Union.

\section{References}

1. J. R. Nicholls, MRS Bulletin 28, 659 (2003).

2. www.particoat.eu

3. B. Rannou, F. Velasco, S. Guzmán, V. Kolarik, F. Pedraza, Materials Chemistry and Physics 134, $360(2012)$.

4. F. Pedraza, M. Mollard, B. Rannou, J. Balmain, B. Bouchaud, G. Bonnet, Materials Chemistry and Physics 134, 700 (2012).

5. X. Montero, M. Galetz, M. Schütze, Surface and Coating Technology 206, 1586 (2011).

6. M. Juez-Lorenzo, V. Kolarik, H. Fietzek, M. Anchústegui, Defect and Diffusion Forum 289-292, 
$261(2009)$.

7. M. Mollard, B. Rannou, B. Bouchaud, J. Balmain, G. Bonnet, F. Pedraza, Corrosion Science 66, $118(2013)$.

8. B. Rannou, Baptiste Bouchaud, J. Balmain, G. Bonnet, F. Pedraza, Oxidation of Metals 81, 139 (2014).

9. A.G. Evans, D.R. Mumm, J.W. Hutchinson, G.H. Meier, F.S. Pettit, Progress in Materials Science 46, 505 (2001).

10. S. Geng, F. Wang, S. Zhu, Oxidation of Metals 57, 231 (2002).

11. J.A. Nychka, D.R. Clarke, G.H. Meier, Materials Science and Engineering A 490, 359 (2008).

12. G. Bonnet, M. Mollard, B. Rannou, J. Balmain, X. Montero, M. Galetz, M. Schütze, Defect and Diffusion Forum 323-325, 381 (2012).

13. M.C. Galetz, X. Montero, M. Mollard, M. Günthner, F. Pedraza, M. Schütze, Intermetallics 44, 8 (2014)

14. V. Kolarik, R. Roussel, M. Juez Lorenzo, H. Fietzek, Materials at High Temperatures 29, 89 (2012).

15. B. Pieraggi, Oxidation of Metals 27, 177 (1987).

16. M.W. Brumm, H.J. Grabke, Corrosion Science 33, 1677 (1992).

17. F.H. Stott, G.C. Wood, J. Stringer, Oxidation of Metals 44, 113 (1995).

18. X. Montero, M.C. Galetz, M. Schütze, Oxidation of Metals 80, (2013) 635-649.

19. C.M.F. Rae, M.S. Hook, R.C. Reed, Materials Sciences and Engineering A 396, 231(2005).

20. B. Bouchaud, J. Balmain, F. Pedraza, Oxidation of Metals 69, 193 (2008).

21. A. Pfennig, B. Fedelich, Corrosion Science 50, 2484 (2008).

22. F. Pedraza, Defect and Diffusion Forum 289-292, 277 (2009).

23. R.C. Pennefather, D.H. Boone, Surface and Coatings Technology 76-77, 47 (1995).

24. B. Bouchaud, J. Balmain, F. Pedraza, Materials Science Forum 595-598, 11 (2008).

25. F.J. Pérez, F. Pedraza, M.P. Hierro, J. Balmain, G. Bonnet, Oxidation of Metals 58, 563 (2002). 
26. F.J. Pérez, F. Pedraza, M.P. Hierro, J. Balmain, G. Bonnet, Surface and Coatings Technology 153, 49 (2002).

27. A. Aguëro, M. Gutiérrez, V. Gonzalez, Materials at High Temperature 25, 257 (2008).

28. A. Aguëro, Energy Materials 1, 35 (2008).

29. V. K. Tolpygo, D. R. Clarke, Acta Materialia 48, 3283 (2000).

30. J. Shi, S. Darzens, A. M. Karlsson, Materials Science and Engineering A 392, 301 (2005).

31. Y.S. Touloukian, R.K. Ki; R.E. Taylor and T.Y.R. Lee. in: Thermophysical Properties of Matter, Thermal Expansion of Nonmetallic Solids Volume 13, p. 176. Plenum, New York (1977).

32. M. W. Chen, K. J. T. Livi, P. K. Wright, K. J. Hemker, Metallurgical and Materials Transactions A 34, 2289 (2003).

33. R.E. Reed, Superalloys, Fundamentals and applications, Chapter 2, p. 35, Cambridge University Press, New York, (2006). 

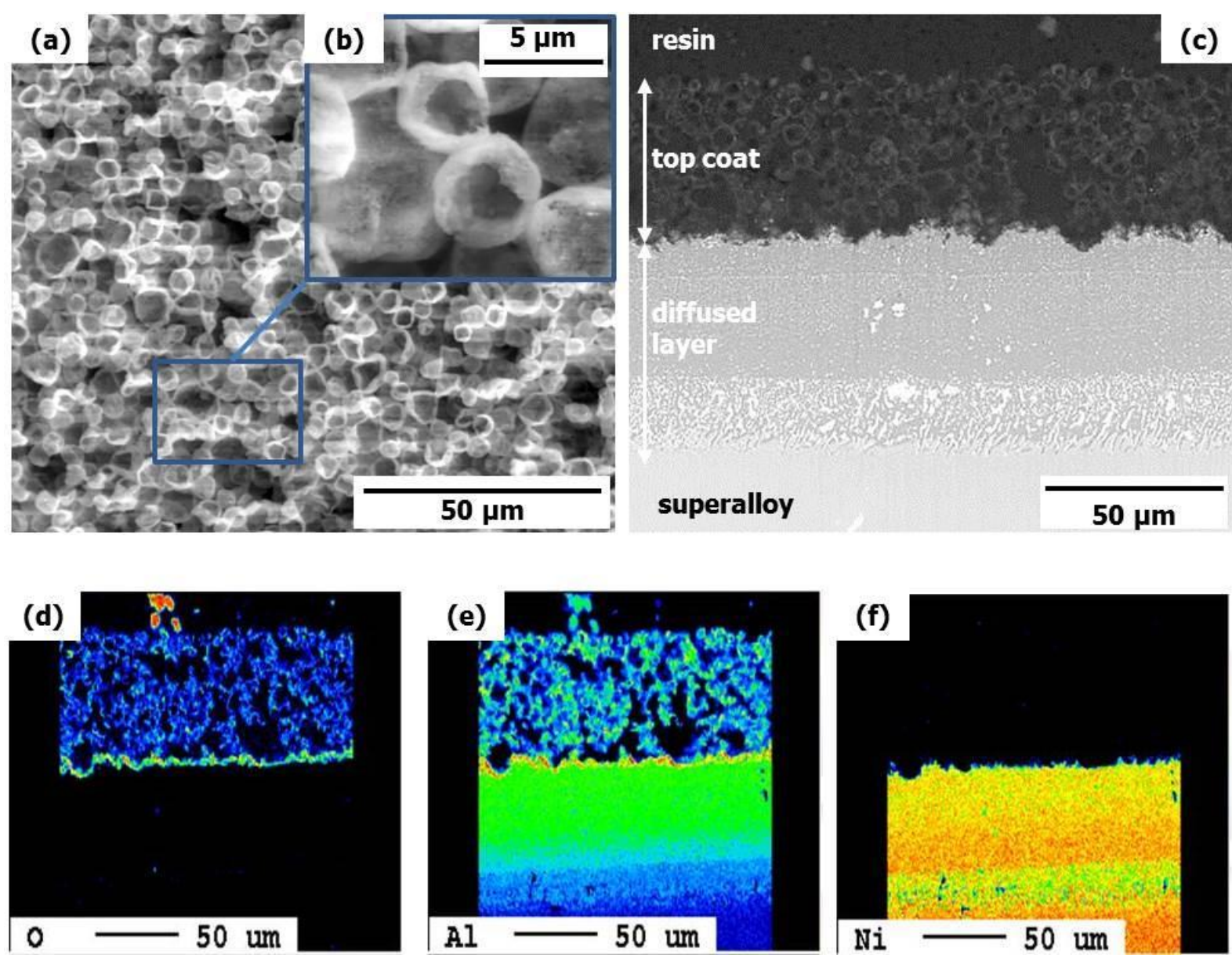

Figure 1.- Slurry TBC coatings investigated. SEM top surface with hollow alumina particles (a), detail of the sintered hollow microparticles (b) and the corresponding cross section with the top coat and the diffused layer over the superalloy substrate (c). EPMA maps of (d) oxygen, (e) aluminium and (f) nickel to reveal the intermediate thermally grown oxide. 
(a)

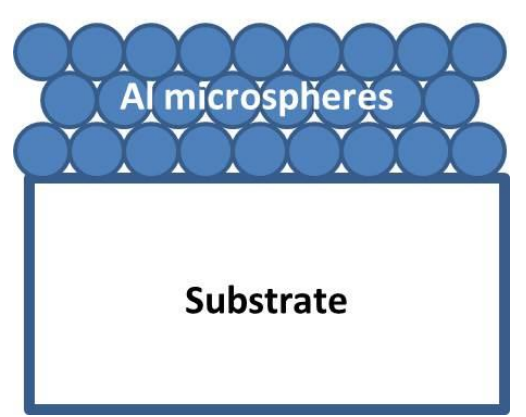

(b)

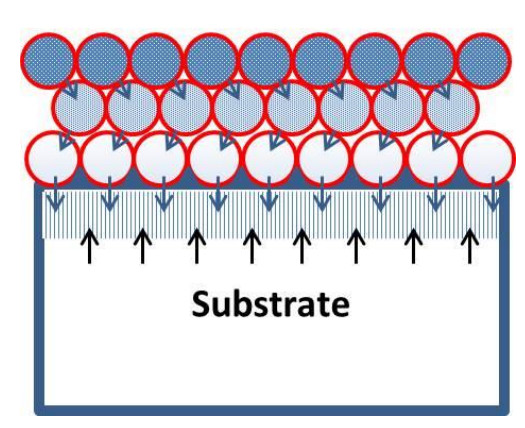

(c)

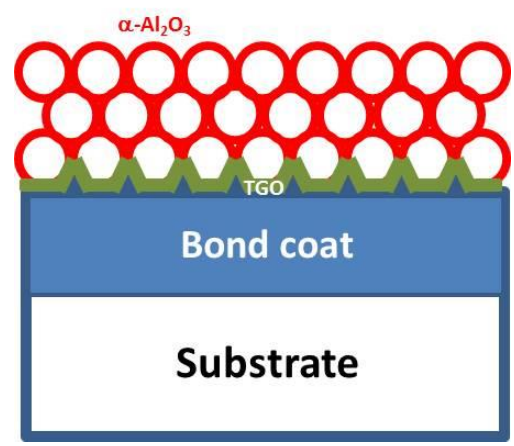

Figure 2.- Schematic illustration of the mechanisms of formation of the slurry TBC coatings. (a) The passivated $\mathrm{Al}$ microspheres lay on the substrate after spray deposition and drying. (b) With increasing temperature Al diffuses into the substrate. The outermost layers of $\mathrm{Al}$ microspheres supply Al to the underlying layers. Ni starts to diffuse outwardly or to solubilise into molten Al. Thickening of the oxide shells occurs. (c) At higher temperatures, the alumina shells transform into the stable $\alpha$ phase. $\mathrm{Al}$ is consumed in the core which leaves behind a hollow structure. Ni diffuses preferentially to $\mathrm{Al}$ to form the $\beta$-NiAl bond coat. 

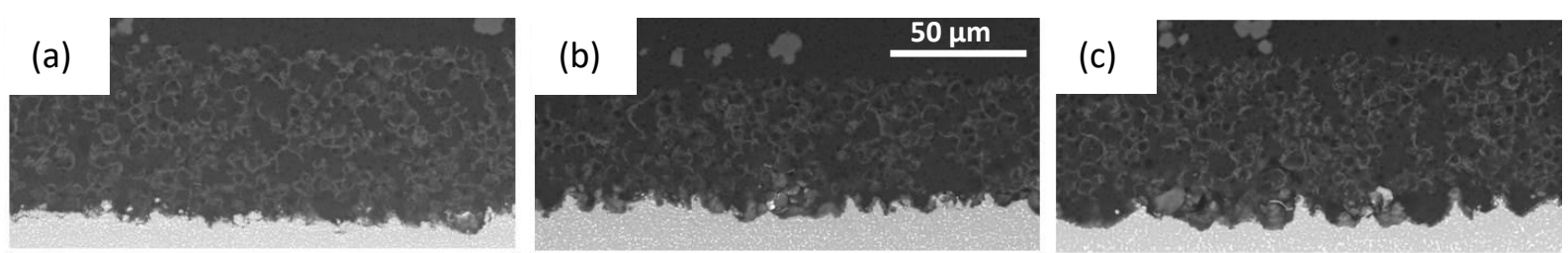

(d)

(e)

(f)

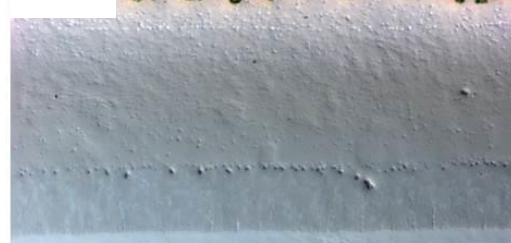

N5 or CM

$20 \mu \mathrm{m}$
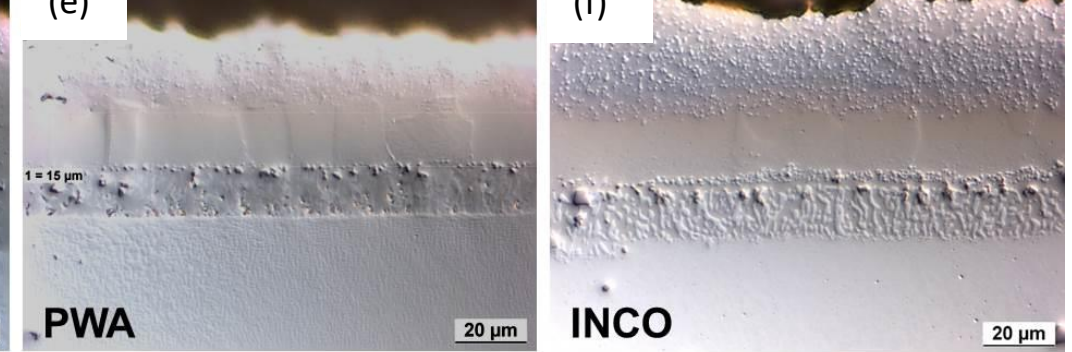

Figure 3.- SEM cross sections of the as a function of superalloy substrate (a) and (d) René N5 or CM-247, (b) and (e) PWA-1483, (c) and (f) IN-738LC. Note the rough interface between the hollow particles and the diffusion layer at the top and the different microstructures of the aluminium diffused layers. 


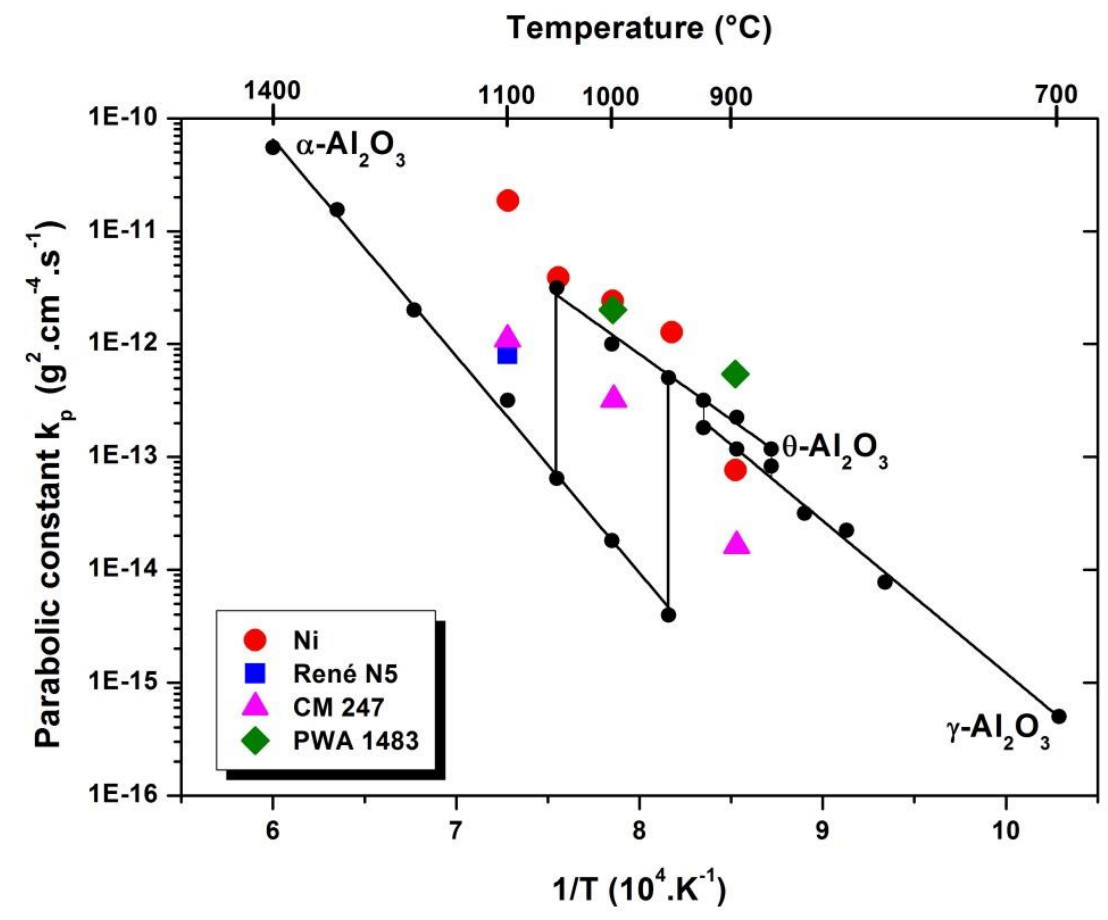

Figure 4.- Arrhenius plot of the $\mathrm{k}_{\mathrm{p}}$ values determined from the oxidation kinetics and comparison with the $\mathrm{k}_{\mathrm{p}}$ values from a pure $\beta$-NiAl [16]. The data for pure $\mathrm{Ni}$ are taken from Ref. [7]. 


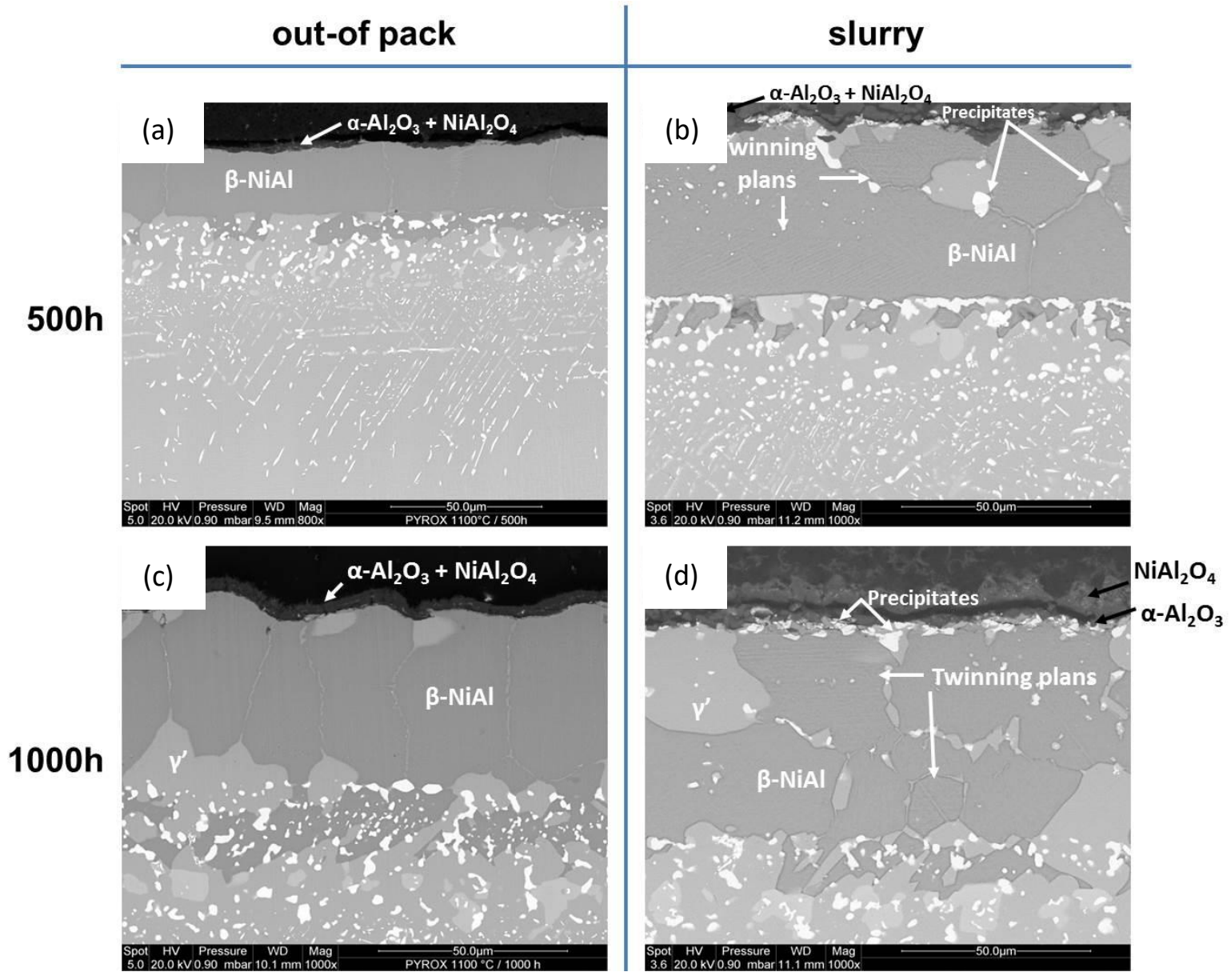

Figure 5.- Evolution of the microstructures in CM-247LC aluminised by (a) and (c) conventional low activity out-of-pack and by (b) and (d) high activity slurry after oxidation at $1100^{\circ} \mathrm{C}$ in air for $500 \mathrm{~h}(\mathrm{a})$ and (b) and for $1000 \mathrm{~h}(\mathrm{c})$ and (d). 


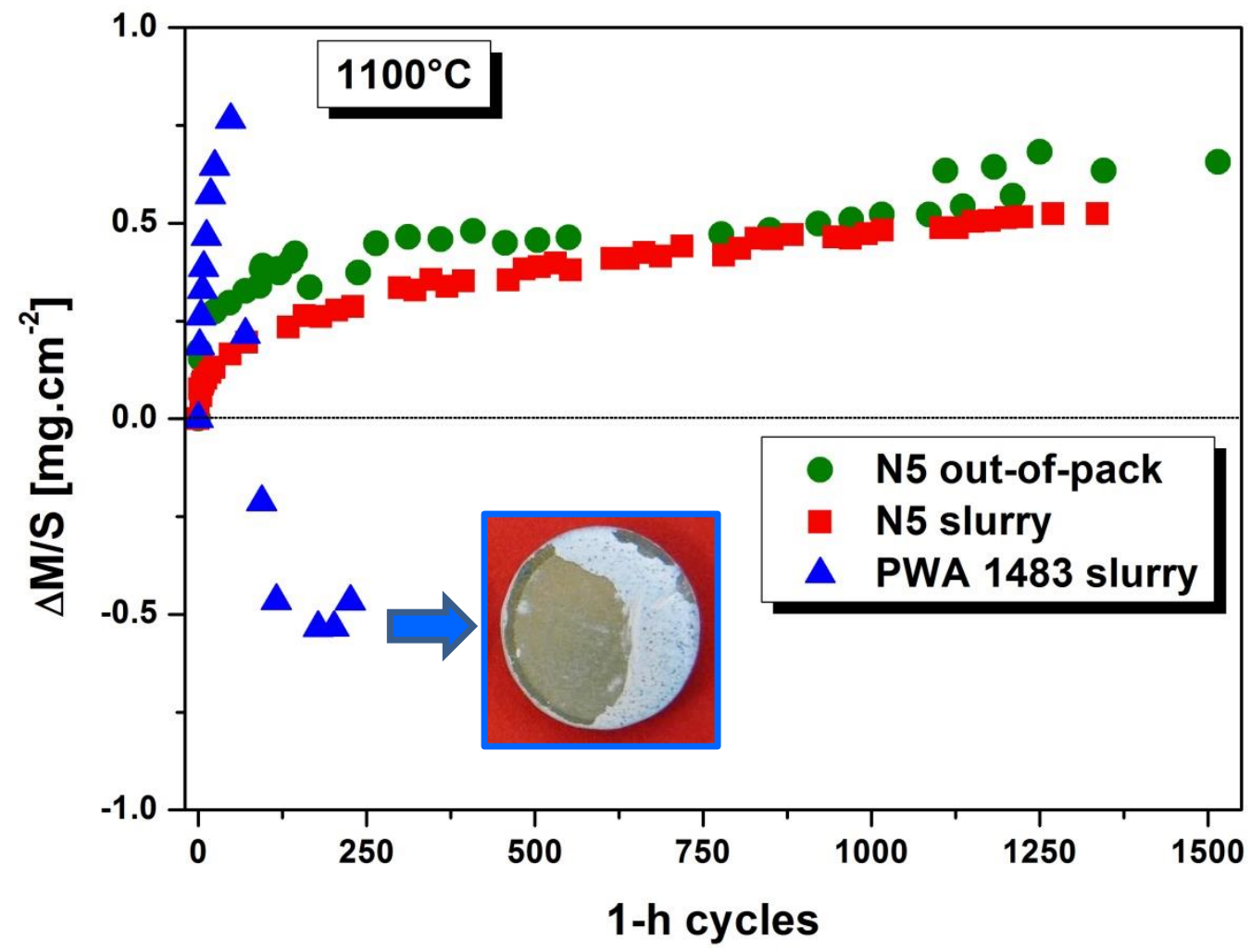

Figure 6.- Evolution of the mass gains per surface unit of the aluminised René N5 and PWA1483 with cyclic oxidation at $1100^{\circ} \mathrm{C}$ in air. Note the great spallation of the slurry aluminised PWA-1483 compared to René N5. 


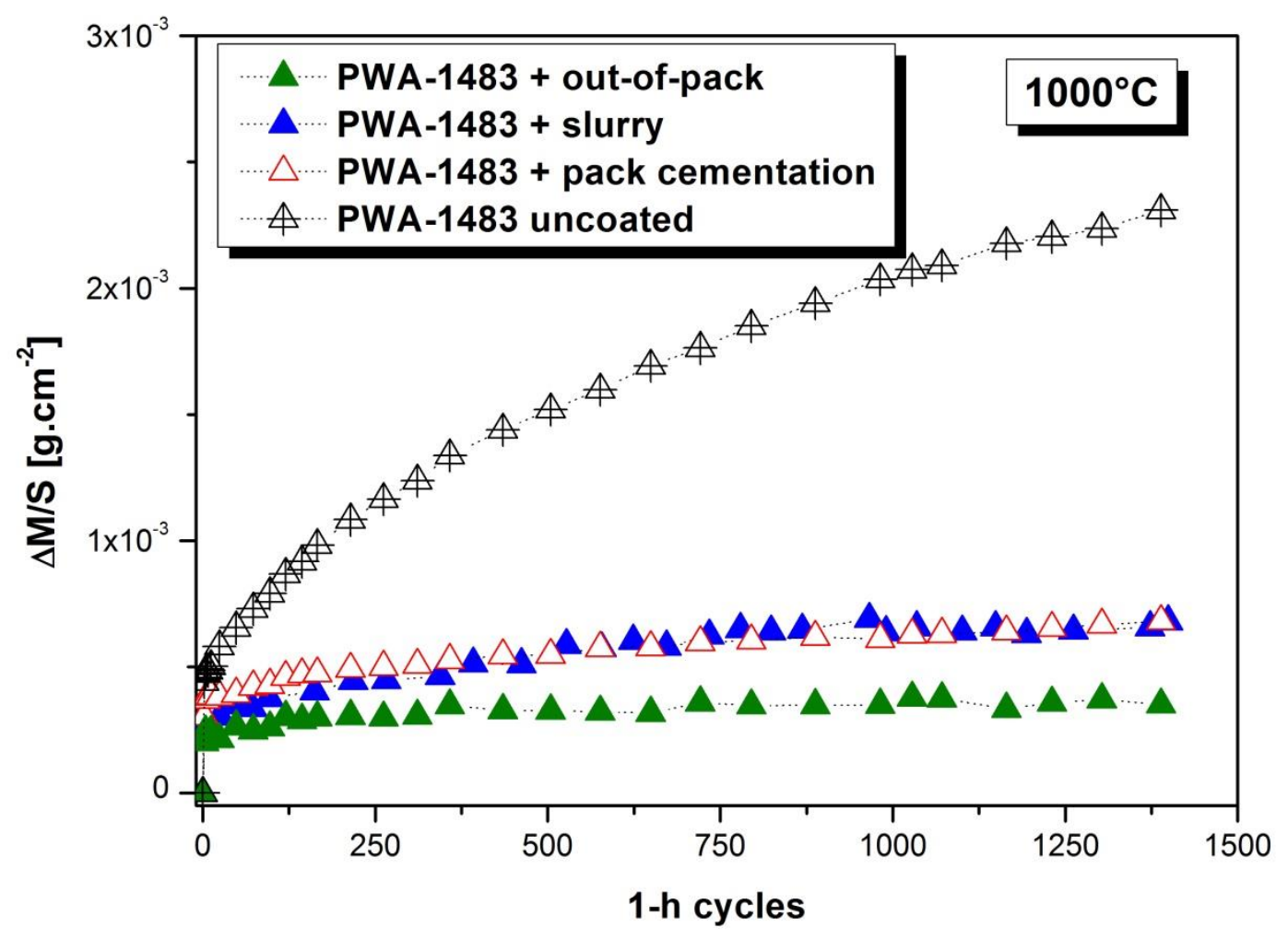

Figure 7.- Evolution of the mass gains per surface unit of the PWA-1483 uncoated and aluminised with different methods with cyclic oxidation at $1000^{\circ} \mathrm{C}$ in air. 


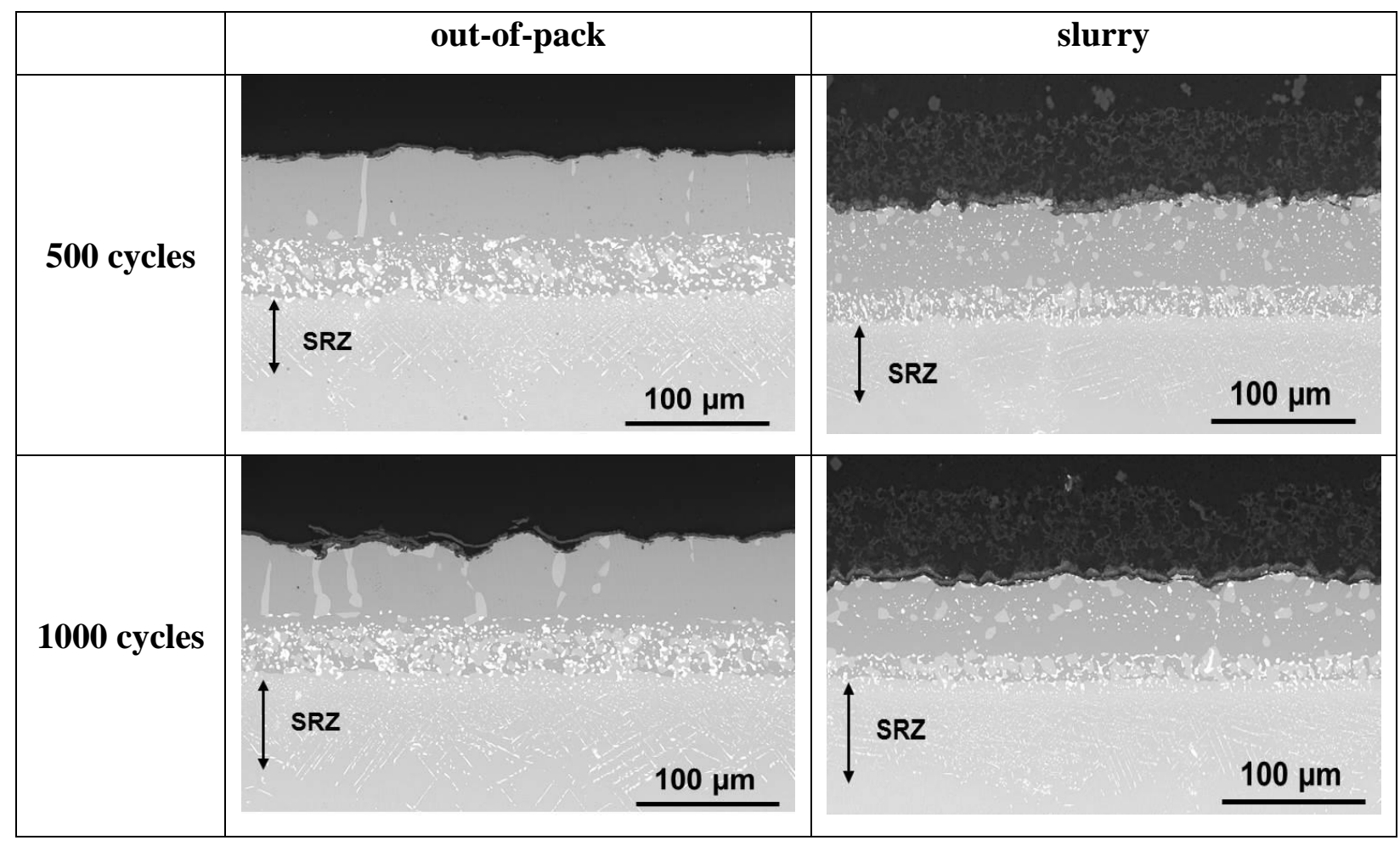

Figure 8.- Evolution of René N5 aluminised by out-of-pack and by slurry with the number of oxidation cycles at $1100^{\circ} \mathrm{C}$ in air. 


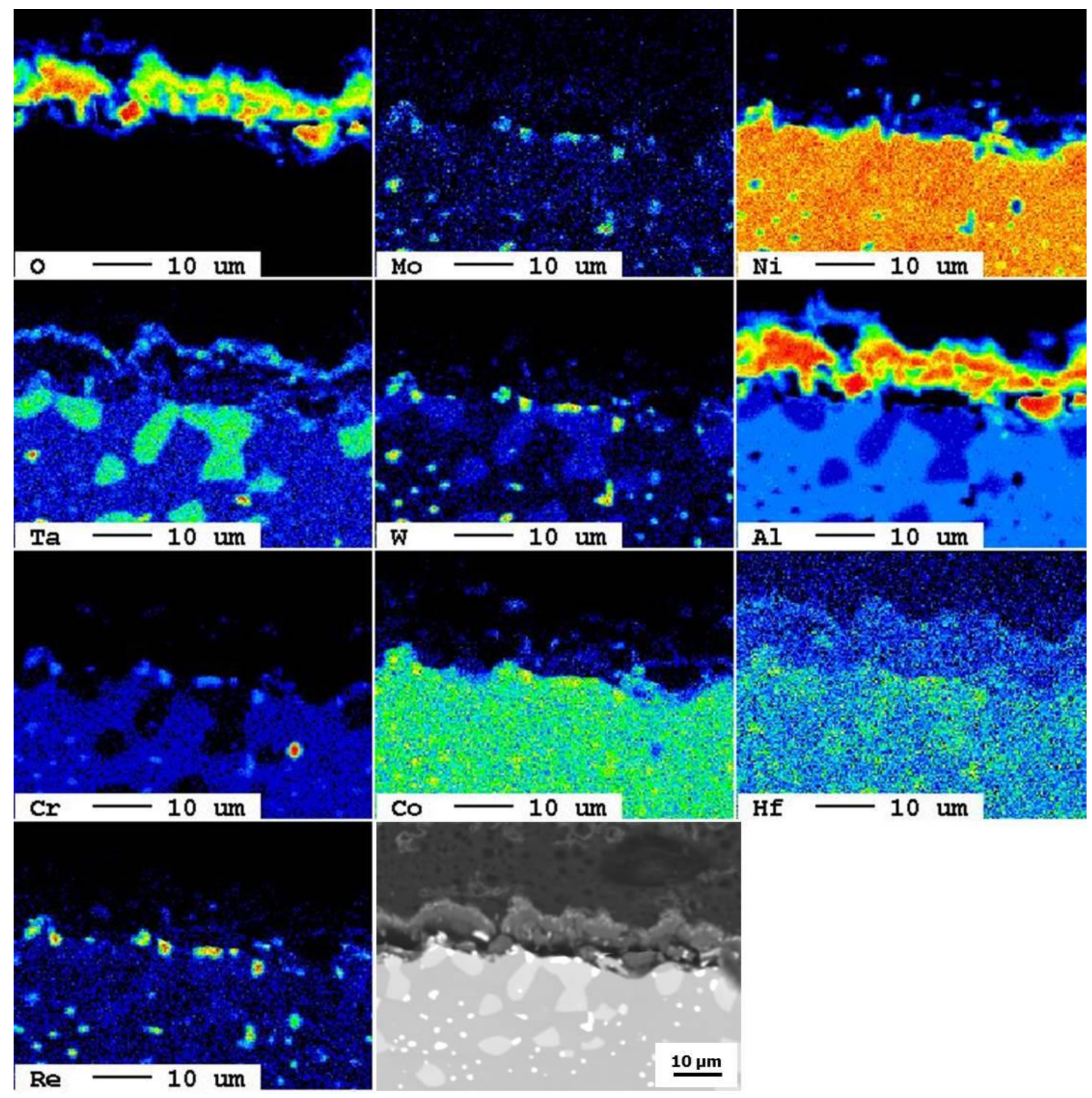

Figure 9.- EPMA X-ray maps of different elements and the SEM cross section of the slurry coated René N5 coated after cyclic oxidation at $1100^{\circ} \mathrm{C}$ in air for 1000 cycles. Note the great partition of Ta to the top of the oxide scale. 
Table 1. Nominal composition (mass\%) of the nickel-based superalloys investigated.

\begin{tabular}{|l|c|c|c|c|c|c|c|c|c|}
\hline & Ni & Cr & Co & Mo & W & Ta & Al & Ti & Other \\
\hline René N5 & 61.6 & 7 & 8 & 2 & 5 & 7 & 6.2 & & $0.2 \mathrm{Hf}, 3.0 \mathrm{Re}$ \\
\hline CM-247LC & 61.7 & 8.1 & 9.2 & 0.5 & 9.5 & 3.2 & 5.6 & 0.7 & $1.4 \mathrm{Hf}$ \\
\hline PWA-1483 & 61.2 & 12.2 & 9 & 1 & 3.8 & 5 & 3.6 & 4.1 & \\
\hline IN-738LC & 61 & 16 & 8.5 & 1.7 & 2.6 & 1.7 & 3.4 & 3.4 & $0.9 \mathrm{Fe}, 0.3 \mathrm{Si}$ \\
\hline
\end{tabular}


Table 2.- Temperatures of oxidation of the different substrates as a function of the regime.

\begin{tabular}{|c|c|c|}
\hline Temperature $\left({ }^{\circ} \mathbf{C}\right)$ & Isothermal & Cyclic \\
\hline $\mathbf{9 0 0}$ & CM-247, PWA-1483, IN-738LC & -- \\
\hline $\mathbf{1 0 0 0}$ & CM-247, PWA-1483 & PWA-1483 \\
\hline $\mathbf{1 1 0 0}$ & CM-247, René N5 & PWA-1483, René N5 \\
\hline
\end{tabular}


Table 3.- Oxide phases identified by XRD and their adherence (visual observations) to the respective coating.

\begin{tabular}{|c|c|c|c|c|}
\hline \multirow{2}{*}{$\begin{array}{c}\text { Oxidation } \\
\text { time (h) }\end{array}$} & \multicolumn{4}{|c|}{ Substrate } \\
\hline & René N5 & CM 247 & PWA 1483 & INCO 738 \\
\hline \multicolumn{5}{|c|}{ Oxidation at $900^{\circ} \mathrm{C}$} \\
\hline \multirow[b]{2}{*}{100} & \multirow[b]{2}{*}{$\mathrm{X}$} & adherent & adherent & \\
\hline & & $\begin{array}{c}\alpha-\mathrm{Al}_{2} \mathrm{O}_{3} / \mathrm{Ta}_{\mathrm{x}} \mathrm{O}_{\mathrm{y}} / \mathrm{TiO}_{2} / \\
\mathrm{HfO}_{2}\end{array}$ & $\alpha-\mathrm{Al}_{2} \mathrm{O}_{3} / \mathrm{TiO}_{2}$ & $\mathrm{X}$ \\
\hline \multirow{2}{*}{500} & \multirow{2}{*}{$\mathrm{X}$} & adherent & adherent & adherent \\
\hline & & $\alpha-\mathrm{Al}_{2} \mathrm{O}_{3} / \mathrm{Ta}_{\mathrm{x}} \mathrm{O}_{\mathrm{y}} / \mathrm{TiO}_{2}$ & $\alpha-\mathrm{Al}_{2} \mathrm{O}_{3} / \mathrm{TiO}_{2}$ & $\alpha-\mathrm{Al}_{2} \mathrm{O}_{3} / \mathrm{TiO}_{2}$ \\
\hline \multirow[b]{2}{*}{1000} & \multirow[b]{2}{*}{$\mathrm{X}$} & adherent & adherent & Adherent \\
\hline & & $\begin{array}{c}\alpha-\mathrm{Al}_{2} \mathrm{O}_{3} / \mathrm{Ta}_{\mathrm{x}} \mathrm{O}_{\mathrm{y}} / \mathrm{TiO}_{2} / \\
\mathrm{HfO}_{2}\end{array}$ & $\begin{array}{c}\alpha-\mathrm{Al}_{2} \mathrm{O}_{3} / \mathrm{NiAl}_{2} \mathrm{O}_{4} / \\
\mathrm{TiO}_{2}\end{array}$ & $\alpha-\mathrm{Al}_{2} \mathrm{O}_{3} / \mathrm{TiO}_{2}$ \\
\hline \multicolumn{5}{|c|}{ 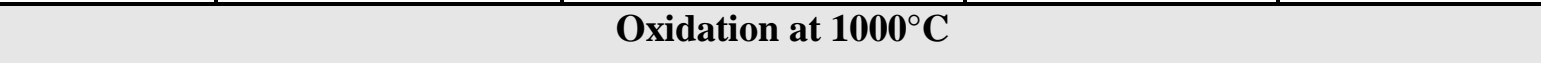 } \\
\hline \multirow[b]{2}{*}{100} & \multirow[b]{2}{*}{$\mathrm{X}$} & adherent & adherent & \multirow[b]{2}{*}{$\mathrm{X}$} \\
\hline & & $\begin{array}{c}\alpha-\mathrm{Al}_{2} \mathrm{O}_{3} / \mathrm{Ta}_{\mathrm{x}} \mathrm{O}_{\mathrm{y}} / \mathrm{TiO}_{2} / \\
\mathrm{HfO}_{2}\end{array}$ & $\begin{array}{c}\alpha-\mathrm{Al}_{2} \mathrm{O}_{3} / \mathrm{NiAl}_{2} \mathrm{O}_{4} / \\
\mathrm{TiO}_{2}\end{array}$ & \\
\hline \multirow[b]{2}{*}{500} & \multirow[b]{2}{*}{$\mathrm{X}$} & adherent & adherent & \multirow[b]{2}{*}{$\mathrm{X}$} \\
\hline & & $\begin{array}{c}\alpha-\mathrm{Al}_{2} \mathrm{O}_{3} / \mathrm{Ta}_{\mathrm{x}} \mathrm{O}_{\mathrm{y}} / \mathrm{TiO}_{2} / \\
\mathrm{HfO}_{2}\end{array}$ & $\begin{array}{c}\alpha-\mathrm{Al}_{2} \mathrm{O}_{3} / \mathrm{NiAl}_{2} \mathrm{O}_{4} / \\
\mathrm{TiO}_{2}\end{array}$ & \\
\hline \multirow[b]{2}{*}{1000} & \multirow[b]{2}{*}{$\mathrm{X}$} & adherent & adherent & \multirow[b]{2}{*}{$\mathrm{X}$} \\
\hline & & $\begin{array}{c}\alpha-\mathrm{Al}_{2} \mathrm{O}_{3} / \mathrm{Ta}_{\mathrm{x}} \mathrm{O}_{\mathrm{y}} / \mathrm{TiO}_{2} / \\
\mathrm{HfO}_{2}\end{array}$ & $\begin{array}{c}\alpha-\mathrm{Al}_{2} \mathrm{O}_{3} / \mathrm{NiAl}_{2} \mathrm{O}_{4} / \\
\mathrm{TiO}_{2} / \mathrm{Ta}_{4} \mathrm{O}\end{array}$ & \\
\hline \multicolumn{5}{|c|}{ Oxidation at $1100^{\circ} \mathrm{C}$} \\
\hline \multirow[b]{2}{*}{100} & adherent & Partially detached & \multirow[b]{2}{*}{$\mathrm{X}$} & \multirow[b]{2}{*}{$X$} \\
\hline & $\begin{array}{c}\alpha-\mathrm{Al}_{2} \mathrm{O}_{3} / \mathrm{Ta}_{\mathrm{x}} \mathrm{O}_{\mathrm{y}} / \\
\mathrm{WO}_{2}\end{array}$ & $\begin{array}{l}\alpha-\mathrm{Al}_{2} \mathrm{O}_{3} / \mathrm{NiAl}_{2} \mathrm{O}_{4} / \\
\mathrm{Ta}_{\mathrm{x}} \mathrm{O}_{\mathrm{y}} / \mathrm{TiO}_{2} / \mathrm{HfO}_{2}\end{array}$ & & \\
\hline \multirow[b]{2}{*}{500} & adherent & Partially detached & \multirow[b]{2}{*}{$\mathrm{X}$} & \multirow[b]{2}{*}{$X$} \\
\hline & $\begin{array}{c}\alpha-\mathrm{Al}_{2} \mathrm{O}_{3} / \mathrm{Ta}_{\mathrm{x}} \mathrm{O}_{\mathrm{y}} / \\
\mathrm{AlTaO}_{4} / \mathrm{WO}_{2}\end{array}$ & $\begin{array}{l}\alpha-\mathrm{Al}_{2} \mathrm{O}_{3} / \mathrm{NiAl}_{2} \mathrm{O}_{4} / \\
\mathrm{Ta}_{\mathrm{x}} \mathrm{O}_{\mathrm{y}} / \mathrm{TiO}_{2} / \mathrm{HfO}_{2}\end{array}$ & & \\
\hline \multirow[b]{2}{*}{1000} & adherent & Partially detached & \multirow[b]{2}{*}{$\mathrm{X}$} & \multirow[b]{2}{*}{$\mathrm{X}$} \\
\hline & $\begin{array}{c}\alpha-\mathrm{Al}_{2} \mathrm{O}_{3} / \mathrm{Ta}_{\mathrm{x}} \mathrm{O}_{\mathrm{y}} / \\
\mathrm{AlTaO}_{4} / \mathrm{WO}_{2}\end{array}$ & $\begin{array}{l}\alpha-\mathrm{Al}_{2} \mathrm{O}_{3} / \mathrm{NiAl}_{2} \mathrm{O}_{4} / \\
\mathrm{Mo}_{\mathrm{x}} \mathrm{O}_{\mathrm{y}} / \mathrm{TiO}_{2} / \mathrm{HfO}_{2}\end{array}$ & & \\
\hline
\end{tabular}


Table 4.- Thickness $( \pm 2 \mu \mathrm{m})$ of TCP extension as a function of oxidation regime, temperature, and time of the slurry coatings on different substrates.

\begin{tabular}{|c|c|c|c|c|c|}
\hline & \multicolumn{5}{|c|}{$900^{\circ} \mathrm{C}$} \\
\hline & \multicolumn{2}{|c|}{ Isothermal } & \multicolumn{3}{|c|}{ Cyclic } \\
\hline & $500 \mathrm{~h}$ & $1000 \mathrm{~h}$ & 500 & 1000 & 1500 \\
\hline CM-247LC & 10 & 16 & $\mathrm{x}$ & $\mathrm{x}$ & $\mathrm{x}$ \\
\hline PWA-1483 & 19 & 28 & $\mathrm{x}$ & $\mathrm{x}$ & $\mathrm{x}$ \\
\hline \multirow[t]{4}{*}{ IN-738LC } & 18 & 23 & $\mathrm{x}$ & $\mathrm{x}$ & $\mathrm{x}$ \\
\hline & \multicolumn{5}{|c|}{$1000^{\circ} \mathrm{C}$} \\
\hline & \multicolumn{2}{|c|}{ Isothermal } & \multicolumn{3}{|c|}{ Cyclic } \\
\hline & $500 \mathrm{~h}$ & $1000 \mathrm{~h}$ & 500 & 1000 & 1500 \\
\hline CM-247LC & 12 & 24 & $\mathrm{x}$ & $\mathrm{x}$ & $\mathrm{x}$ \\
\hline \multirow[t]{4}{*}{ PWA-1483 } & 21 & 36 & 21 & 24 & 29 \\
\hline & \multicolumn{5}{|c|}{$1100^{\circ} \mathrm{C}$} \\
\hline & \multicolumn{2}{|c|}{ Isothermal } & \multicolumn{3}{|c|}{ Cyclic } \\
\hline & $500 \mathrm{~h}$ & $1000 \mathrm{~h}$ & 500 & 1000 & 1500 \\
\hline CM-247LC & 6 & 12 & $\mathrm{x}$ & $\mathrm{x}$ & $\mathrm{x}$ \\
\hline René N5 & 45 & 62 & 39 & 44 & 60 \\
\hline
\end{tabular}


Table 5.- Oxide phases identified by XRD for the different aluminide coatings on PWA1483 after cyclic oxidation at $1000^{\circ} \mathrm{C}$ in air. (NB: the symbols > and > indicate, respectively, greater or much greater relative intensity of the phase in the patterns).

\begin{tabular}{|c|c|c|c|}
\hline & 500 cycles & 1000 cycles & 1500 cycles \\
\hline \multirow[b]{2}{*}{ slurry } & $\beta-\mathrm{NiAl}$ & $\beta-\mathrm{NiAl} \gg \gamma^{\prime}-\mathrm{Ni}_{3} \mathrm{Al}$ & $\beta-\mathrm{NiAl}>\gamma^{\prime}-\mathrm{Ni}_{3} \mathrm{Al}$ \\
\hline & $\alpha-\mathrm{Al}_{2} \mathrm{O}_{3}>\mathrm{TiO}_{2}$ & $\begin{array}{c}\alpha-\mathrm{Al}_{2} \mathrm{O}_{3}>\mathrm{TiO}_{2}>> \\
\mathrm{NiAl}_{2} \mathrm{O}_{4}\end{array}$ & $\begin{array}{c}\alpha-\mathrm{Al}_{2} \mathrm{O}_{3}>\mathrm{TiO}_{2}>> \\
\mathrm{NiAl}_{2} \mathrm{O}_{4}\end{array}$ \\
\hline \multirow{2}{*}{$\begin{array}{c}\text { Pack } \\
\text { cementation }\end{array}$} & $\beta-\mathrm{NiAl}$ & $\beta-\mathrm{NiAl} \gg \gamma^{\prime}-\mathrm{Ni}_{3} \mathrm{Al}$ & $\beta-\mathrm{NiAl}>\gamma^{\prime}-\mathrm{Ni}_{3} \mathrm{Al}$ \\
\hline & $\alpha-\mathrm{Al}_{2} \mathrm{O}_{3}>\mathrm{TiO}_{2}$ & $\begin{array}{c}\alpha-\mathrm{Al}_{2} \mathrm{O}_{3}>\mathrm{TiO}_{2}>> \\
\mathrm{NiAl}_{2} \mathrm{O}_{4}\end{array}$ & $\begin{array}{c}\alpha-\mathrm{Al}_{2} \mathrm{O}_{3}>\mathrm{TiO}_{2}>> \\
\mathrm{NiAl}_{2} \mathrm{O}_{4}\end{array}$ \\
\hline \multirow[b]{2}{*}{ Out-of-pack } & $\beta-\mathrm{NiAl}$ & $\beta-\mathrm{NiAl}$ & $\beta-\mathrm{NiAl}>\gamma^{\prime}-\mathrm{Ni}_{3} \mathrm{Al}$ \\
\hline & $\begin{array}{c}\alpha-\mathrm{Al}_{2} \mathrm{O}_{3} \gg> \\
\mathrm{NiAl}_{2} \mathrm{O}_{4}\end{array}$ & $\alpha-\mathrm{Al}_{2} \mathrm{O}_{3} \gg \mathrm{NiAl}_{2} \mathrm{O}_{4}$ & $\alpha-\mathrm{Al}_{2} \mathrm{O}_{3} \gg \mathrm{NiAl}_{2} \mathrm{O}_{4}$ \\
\hline
\end{tabular}

